\title{
MODAL PARAMETER IDENTIFICATION OF CABLE STAYED BRIDGE BASED ON EXPLORATORY DATA ANALYSIS
}

\author{
I. KHAN $^{1}$, D. SHAN ${ }^{2}$, Q. LI $^{3}$
}

\begin{abstract}
In order to identify the modal parameters of civil structures it is vital to distinguish the defective data from that of appropriate and accurate data. The defects in data may be due to various reasons like defects in the data collection, malfunctioning of sensors, etc. For this purpose Exploratory Data Analysis (EDA) was engaged to envisage the distribution of sensor's data and to detect the malfunctioning with in the sensors. Then outlier analysis was performed to remove those data points which may disrupt the accurate data analysis. Then Data Driven Stochastic Sub-space Identification (DATA-SSI) was engaged to perform the modal parameter identification. In the end to validate the accuracy of the proposed method stabilization diagrams were plotted. Sutong Bridge, one of the largest span cable stayed bridge was used as a case study and the suggested technique was employed. The results obtained after employing the above mentioned techniques are very valuable, accurate and effective.
\end{abstract}

Keywords: EDA, DATA-SSI, outlier analysis, stabilization diagram

\section{INTRODUCTION}

As the civil infrastructure especially the long span bridges are aging with time, the importance for an economically sustainable maintenance also increases [1].

\footnotetext{
${ }^{1}$ PhD. INAMULLAH KHAN, Bridge Engineering Department, Civil Engineering School, Southwest Jiaotong University, P.O. Box 610031, Chengdu, Sichuan Province, China, e-mail: inam_bunny@yahoo.com

${ }^{2}$ Prof., DESHAN SHAN, Bridge Engineering Department, Civil Engineering School, Southwest Jiaotong University, P.O. Box 610031, Chengdu, Sichuan Province, China, e-mail: dsshan@home.swjtu.edu.cn

${ }^{3}$ Prof., QIAO LI, Bridge Engineering Department, Civil Engineering School, Southwest Jiaotong University, P.O. Box 610031, Chengdu, Sichuan Province, China, e-mail: 2475778063@qq.com
} 
Due to the traditional visual inspection techniques, which are time consuming and expensive, it is vital to develop a more reliable and efficient monitoring system for these long span cable stayed bridges to continuously monitor its structural performances for fast and accurate data analysis [2]. The capricious nature of the civil structures especially the long span bridges due to the abnormal data obtained from these long span bridges have made the monitoring process further complicated. The data obtained from these sensor's installed at these long span cable stayed bridges, need to be trustworthy, so that a reliable and comprehensive data analysis can be carried out [3,4]. Since there are anomalies in the monitoring system due to malfunctioning of sensors or monitoring system failure, thus an effective and efficient technique is required, which can quickly detect these anomalies and present them in a more professional way. Therefore a graphical method called Exploratory Data Analysis (EDA) has been introduced in this paper. EDA was first introduced by [5] in 1971, it is basically a data visualization tool, and in the past many authors used it just for making graphs, because the technology was not so much advanced [6-12]. [13] performed EDA on a simple experimental data and the data size was very small. Thus his method is not applicable for anomaly detection of large scale data analysis.

In last few decades, the modal parameters identification is gradually becoming more important, because it has provided innovative tools for understanding and controlling the optimization of design and assessment of structural health [14]. During the past few years the stochastic subspace identification (SSI) had been successfully applied on the structures for output-only system identification. There are basically two important numerical tools for subspace methods in linear algebra, first; Singular Value Decomposition (SVD) and secondly; the QR decomposition [15]. For large scale civil structures such as long span cable stayed bridges, the output-only SSI is very effective for identification and monitoring of these structures due to ambient vibrations. There are various SSI techniques such as Covariance Driven SSI, Data Driven (DATA-SSI), or combination of others methods, like expectation Maximization technique (EM-SSI) [16, 17], and the Empirical Mode Decomposition (EMD) based SSI techniques [18]. DATA-SSI algorithms were fully enhanced by [19]. The main output-only identification in the DATA-SSI techniques is the orthogonal projections performed by LQ decomposition $[19,20]$. Then it is followed by the SVD to extract the subspace system. In DATA-SSI there are variants which correspond to different choices for weighting the matrices before factorization the projection matrix. [21] studied the DATA-SSI to investigate the dynamic characteristics but his technique was only for discrete time and not for continuous time. [22] applied DATA-SSI algorithm to the identification of a steelquake bench mark, but it was not employed for some real life data. [23] applied the DATA-SSI 
to a Heritage court tower in Vancouver, Canada, but was having some problems. [24] applied reference based SSI algorithm to steel mast but was also based on discrete time. Therefore in this paper DATA-SSI with some improvements were applied to the real life long span cable stayed bridge. The flow chart of modal parameter identification process is shown in Fig. 1.

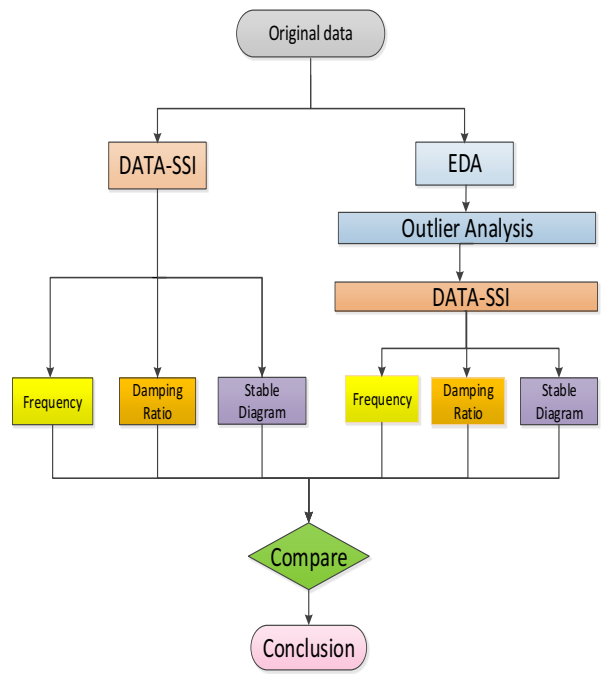

Fig. 1. Flow Chart for identification process

\section{EDA}

For large scale data it is practically impossible to make sense out of data sets containing more than a handful of data points without a powerful technique. Since the data obtained from the health monitoring of bridges are usually in a very huge amount and a little is known about probability density functions (PDF's), therefore it is always advisable to the engineer to examine the data to determine and point out the underlying features in the data before applying quantitative techniques, but the main hurdle for an engineer is the time [25]. Since the data is very huge, so it consumes very large computation time to go through the data set and identify the underlying features in the data set. Therefore EDA is the most powerful tool to aid the engineer to explore the inner secrets in the data in a detailed fashion with a very less computation time period. Thus the exploratory nature of EDA may be sufficient for many SHM applications [25]. Therefore numerous techniques are available for graphical representation of data, but here in this paper only 
few will be used to demonstrate the accuracy and efficiency of EDA such as Control charts, Andrew's curves and Histograms.

\section{OUTLIER ANALYSIS}

Outlier is an observation which deviates so much from the rest of observations and arouse doubts, that it was generated by a different mechanism [26]. Outliers are generally due to the abnormalities or anomalies in the data, thus its behaviour is usually suspicious. Outliers can be defined in a number of ways in a given data set, but it depends on the application specific scenarios. In case of SHM campaigns outlier analysis is very important, because most of the times the sensors starts producing abnormal data and if it is not properly treated, the whole data analysis is affected and can leads to false structure information. Secondly the SSI techniques are sensitive to outliers, thus if there are presence of outliers, the whole identification process will be distracted. Therefore after performing the EDA, it was imperative in this paper to perform an outlier analysis. There are a number of ways to detect the outliers by discordancy tests, but one of the most powerful one which can be easily employed to the data set is based on deviation statistics and is given as:

$$
z_{\xi}=\frac{\left|x_{\xi}-\bar{x}\right|}{s}
$$

where $x_{\xi}$ is the potential outlier and $\bar{x}$ is the mean, whereas $s$ is the standard deviation of the sample and here in this paper it is kept as 3 .

\section{DATA DRIVEN STOCHASTIC SUBSPACE IDENTIFICATION}

\subsection{NUMERICAL MODELLING}

The ambient excitation of a dynamic system of a bridge structure under classical formulation can be expressed as:

$$
\mathrm{m} \ddot{x}(t)+c \dot{x}(\mathrm{t})+k x(t)=f v(t)
$$


where " $\mathrm{m}$ " is the mass, "c" is the damping coefficient and " $\mathrm{k}$ " is the stiffness, $\mathrm{x}$ " $(t), \mathrm{x}$ ( $(\mathrm{t})$ and $\mathrm{x}(\mathrm{t})$ are the acceleration, speed and displacement vector at time instant $t$ respectively. " $f$ " is the input matrix of the force excitation and $v(\mathrm{t})$ is the input vector at time instant $t$. Now considering the discrete form, DATA-SSI method performs the identification of the modal parameters using the state space model by the following equations:

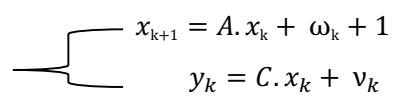

Where $x_{k}$ is the discrete time state vector at time instant $\mathrm{k}, y_{k}$ is a vector with the sampled outputs, $\mathrm{A}$ and $\mathrm{C}$ are the discrete state and output matrix respectively and $\omega_{k}, v_{k}$ are state noise and modelling in accuracies vectors respectively.

The data driven stochastic subspace identification (DATA-SSI) techniques utilizes Projection matrix created from the Hankel matrix as compare to the covariance driven stochastic subspace identification (CO-SSI). Secondly the calculation needs less memory due to the Projection method, even though this makes the principle of the method a little bit more complex, but still it is more efficient as compare to CO-SSI.

In case of DATA-SSI the number of block rows and columns in the Hankel matrix plays a very important role and thus the influence on the identification process is very prominent, the block columns must be larger than the block rows, and the rows are generally multiplied with the number of sensors, so the column number of the Hankel matrix in case of DATA-SSI is larger as compare to COSSI method. The given Hankel matrix in case of DATA-SSI can be determined from the output data, computing the projection matrix of the row space of future into the row space of the past. In general using RQ decomposition on the Hankel matrix to calculate two projection matrices $P_{i}, P_{i+1}$, the Hankel matrix can be expressed as:

$$
\text { Hankel }=\left[\begin{array}{cccc}
y_{0} & y_{1} & y_{2} & \cdots \\
y_{1} & y_{2} & y_{3} & \cdots \\
y_{2} & y_{3} & y_{4} & \cdots \\
\vdots & \vdots & \vdots & \ddots
\end{array}\right]=\left[\frac{y_{p}}{y_{f}}\right]
$$


After performing the RQ Decomposition, it can be written as:

$$
\begin{aligned}
& \text { Hankel }=R Q=\left[\begin{array}{cccc}
R_{11} & 0 & 0 & 0 \\
R_{21} & R_{22} & 0 & 0 \\
R_{31} & R_{32} & R_{33} & 0 \\
R_{41} & R_{42} & R_{43} & R_{44}
\end{array}\right]\left[\begin{array}{c}
Q_{11} \\
Q_{12} \\
Q_{13} \\
Q_{14}
\end{array}\right] \\
& P_{i}=\left[\begin{array}{ll}
R_{31} & R_{32} \\
R_{41} & R_{42}
\end{array}\right]\left[\begin{array}{l}
Q_{11} \\
Q_{12}
\end{array}\right]
\end{aligned}
$$

$$
P_{i+1}=\left[\begin{array}{lll}
R_{41} & R_{42} & R_{43}
\end{array}\right]\left[\begin{array}{l}
Q_{11} \\
Q_{12} \\
Q_{13}
\end{array}\right]
$$

In order to get the observability matrix $\mathrm{O}_{\mathrm{i}}$. Singular value decomposition is performed on the projection matrix $\mathrm{P}_{\mathrm{i}}$ to get:

$$
P_{i}=U S V^{T}=\left[\begin{array}{ll}
U_{1} & U_{2}
\end{array}\right]\left[\begin{array}{cc}
\Sigma_{1} & 0 \\
0 & \sum_{2}=0
\end{array}\right]\left[\begin{array}{c}
V_{1}^{T} \\
V_{2}^{T}
\end{array}\right]
$$

The observability matrix and kalman filter state space sequence can be computed as:

$$
O_{i}=U_{1} S_{1}^{1 / 2} T
$$

$$
\hat{S}_{i}=\left[O_{i}\right]^{+}\left[P_{i}\right]
$$

where the similarity transformation $[\mathrm{T}]$ can be set equal to the identity matrix. A factorization can be applied to $\left[P_{i+1}\right]$, thus obtaining:

$$
\left[P_{i+1}\right]=\left[O_{i}^{\uparrow}\right]\left[\hat{S}_{i+1}\right]
$$

$$
\left[\hat{S}_{i+1}\right]=\left[O_{i}^{\uparrow}\right]^{+}\left[P_{i+1}\right]
$$


Hence the system matrix A can be written as follow:

$$
A=x_{i+1} x_{i}^{-1}
$$

Then using the last block row output data matrix $y_{i} / l i$ and multiply the inverse Kalman filtered state matrix $x_{i}$ to get the system matrix $\mathrm{C}$ and thus it can be written as:

$$
C=y_{i / l i} x_{i}^{-1}
$$

Therefore the eigenvalue and the eigenvector can be obtained by eigenvalue decomposition on the system matrix A and can be written as:

$$
A=\psi \Lambda \psi^{-1}
$$

In order to convert from discrete time to continuous time, the relation between the poles in $\mathrm{z}$ domain and those in the Laplace domain is given as:

$$
z_{r}=e^{\lambda_{r} \Delta t} \Rightarrow \lambda_{r}=\frac{\ln \left(z_{r}\right)}{\Delta t}
$$

Hence the frequency and the damping ratio can be found from the equations given below:

$$
f_{r}=\frac{\left|\lambda_{r}\right|}{2 \pi}
$$

$$
\xi_{r}=-\frac{\operatorname{Re}\left(\lambda_{r}\right)}{\lambda_{r}}
$$

\subsection{STABILIZATION DIAGRAM}

In case of real life large scale civil engineering structures, noise and perturbations are always present in the measured data and generally there is no prior information about the number of modes that need to be extracted from the data. The main reason for no prior information is the uncertainties present in the determination of system order. Therefore a stabilization diagram is used to differentiate between noise or spurious poles and true system poles. The stabilization diagram 
is actually the pictorial representation of the pole occurrence at same frequency due to the increasing modal order to give the physical state of the system order. Based on the procedure of DATA-SSI, stabilization diagram were plotted for the data collected from Sutong bridge.

\section{A CASE STUDY}

\subsection{SUTONG BRIDGE}

Sutong bridge is located on Yangtze River and is one of the longest spanning cable-stayed bridge connecting the cities Suzhou and Nantong [2]. The bridge is a seven span double pylon and double cable plane steel box girder cabled-stayed bridge having a main span of $1088 \mathrm{~m}$, while the overall arrangement of span is $100+100+300+1088+300+100+100=2088 \mathrm{~m}$ [2]. To identify the modal parameters of Sutong Bridge the data was collected from 14 accelerometers sensors installed at the bridge [2]. The huge amount of data collected from the SHM system at Sutong Bridge was first visualized by EDA to discover the underlying secrets and trends in the data, because graphical representation of data is fast and accurate representation of data and save large amount of computation time. Then outlier analysis was performed to remove those data points from the sensor's data which were suspicious and were outliers. Finally DATA-SSI algorithm was employed to get the required modal parameters, such as frequency and damping ratio.

\subsection{OUTLIER ANALYSIS}

Outlier analysis was performed on the sensor's data of Sutong cable stayed Bridge to pre-treat the data prior to perform modal parameter identification. Each of the 14 accelerometer sensors were investigated one by one to detect the potentials outliers and then those data points which were detected as outliers were discarded and remaining data was used for further data analysis. The value for standard deviation was kept at 3 for better outlier analysis. Due to space limitation and huge volume of data, only one sensor i.e. sensor \#3 is shown here in this paper with data set of 7 days from 01-08-2011 to 07-08-2011. Fig. 2(a), shows the original accelerometer sensor\#3 data, whereas Fig. 2(b), shows the accelerometer sensor\#3 data after performing the outlier analysis. The red circles in the Fig. 2(b), shows the outliers, whereas the blue steric shows the original data. Similarly all the 14 sensors were treated and outliers were detected and discarded to make the modal parameter identification accurate and reliable. 


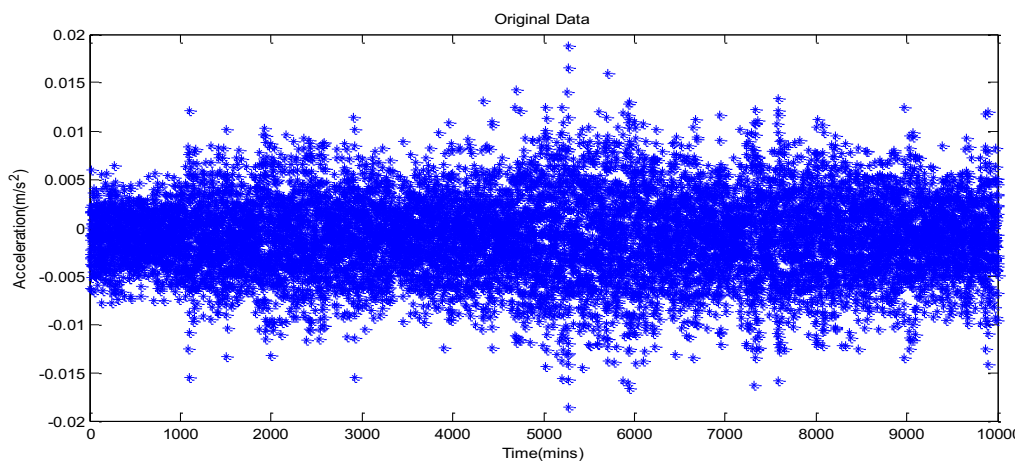

a) Original sensor \# 3 data

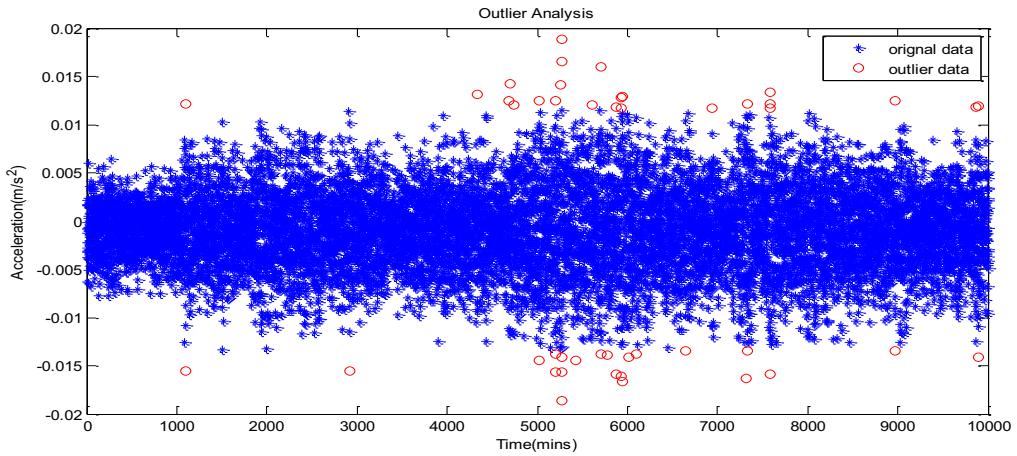

b) After outlier analysis for sensor \# 3

Fig. 2. Outlier analysis for sensor \# 3

\subsection{CONTROL CHARTS}

Control charts are one of the best technique to graphically visualize the stability and patterns in the data to check whether the acquired data is within the specified limits or otherwise. Control charts has one central line for average, an upper line for upper control limit and a lower line for lower control limit. Control charts are one of the best tools for time series data, like our acceleration data. Therefore by plotting the control charts for a time varying data, it's easy for an engineer to quickly detect the anomalies in the sensors data. In this paper control charts were plotted for all the 14 sensors to show the variation in the acceleration data over a certain period of time. First 10, 000 data points were used to see the trend in the acceleration data. The results 
attained in Fig. 3, after plotting the control charts shows that sensor\#1, 2, 9, 12, 13 and 14 are not within the limits and shows some discontinuity and abnormal behaviour, thus unsuitable to be used for modal parameter identification, whereas the results acquired from sensor\#3, 4, 5, 6, 7, 8, 10 and 11 are within the control limits and show very good variation over time, thus showing an accurate representation of acceleration data, hence can be used for accurate and reliable modal parameter identification.
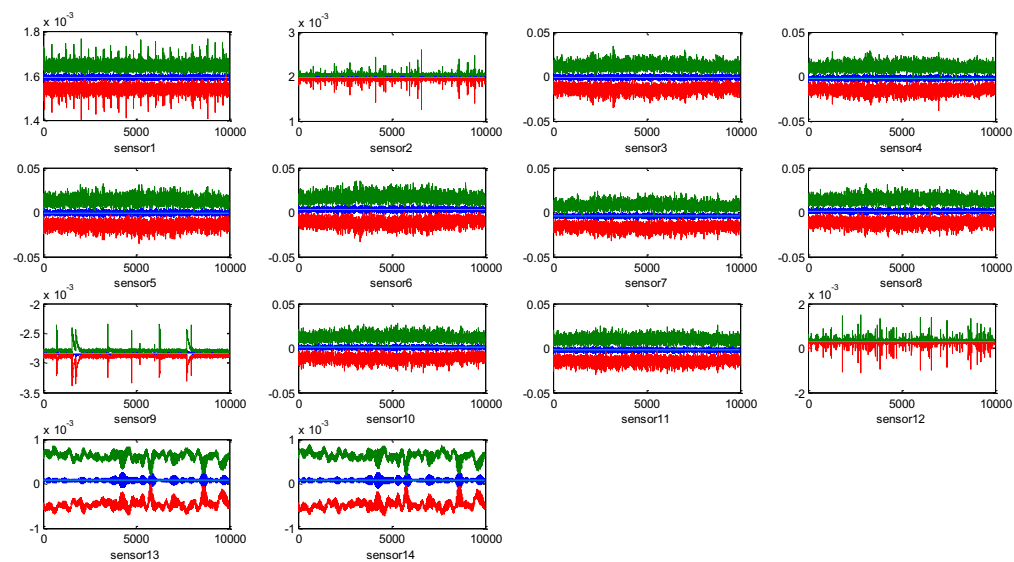

Fig. 3. Control charts

\subsection{ANDREW CURVES}

Andrews's curves were developed as a method for visualizing multi-dimensional data by mapping each observation onto a function [27]. The Andrew's function is defined as:

$$
f_{x}(t)=x_{1} \div 2+x_{2} \sin t+x_{3} \cos t+x_{4} \sin 2 t+x_{5} \cos 2 t+\ldots
$$

where the range of $t$ is given by $-\pi \leq t \leq \pi$. We can see from the above Equation, that each observation is projected onto a set of orthogonal basis functions represented by sines and cosines, and that each sample point is now represented by a curve. Since Andrew curves are very beneficial for multivariate data sets as is our case to depict the useful trends in the more complex data and to extract some meaningful results. In our case the data acquired from 14 accelerometers were 
graphically represented by drawing the Andrew curves as shown in Fig. 4. From Fig. 4, it can be deduced that sensor\#1, 2, 9, 12,13 and 14 are showing abnormal values and the curves are not following the sine and cosine trend, whereas seonsor\#3, 4, 5, 6, 7, 8, 10 and 11 are within the normal limits and can be used for modal parameter identification.
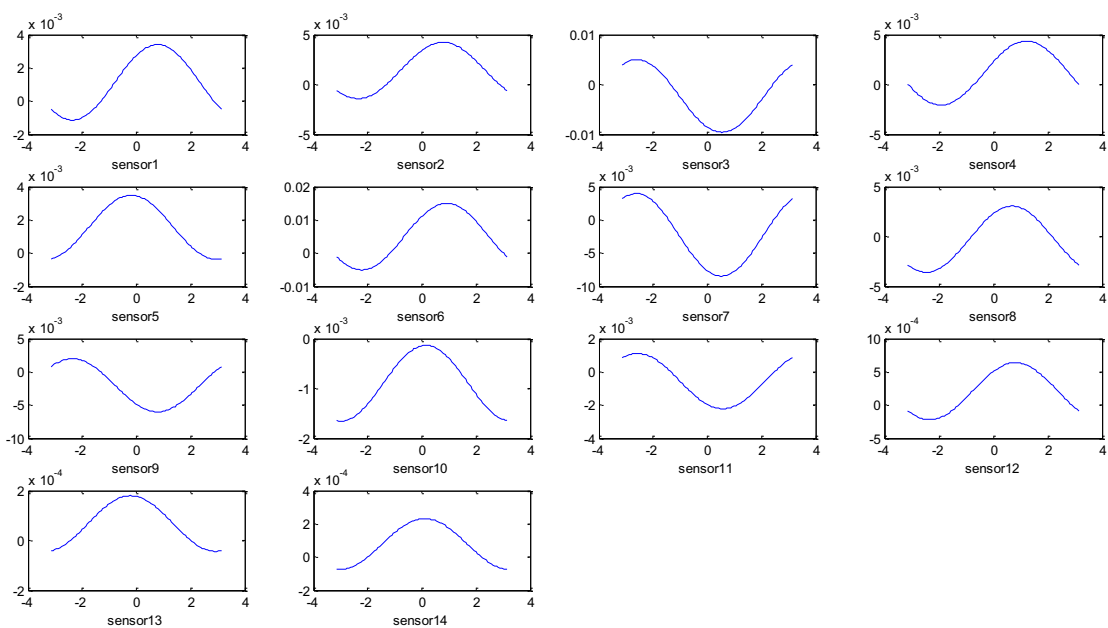

Fig. 4. Andrew curves

\subsection{HistogRAMS}

Since very less is known about PDF's, therefore the simplest non-parametric approach to determine the PDF from the complex data is to construct the histograms. Histograms are generally constructed by choosing an origin $x_{0}$ and a bin width $h$ for a given data. The intervals of the bin width can simply be written as [28]:

$$
\left[x_{0}+m h, x_{0}+(m+1) h\right]
$$

Therefore the histogram can be defined as [28]:

$$
\left.\hat{P}(x)=\frac{1}{n h} \text { (number of points in same bin as } \mathrm{x}\right)
$$


where $\hat{P}(x)$ denotes the true density. The histograms are usually a very quick way to provide useful information about the data. Therefore from view point of SMH histograms provides very quick detection of anomalies in the sensor's data and can be used as a tool to detect anomalies in the large data in short period of time.

In this paper the data acquired from 14 accelerometer sensors were used to plot the histograms as shown in Fig. 5. It can be deduced from Fig. 5, that sensor\#1, 2, 9, 12, 13 and 14 does not follow the normal distribution and especially sensor\#2, 9 and 12 shows abnormal values, hence the data from these sensors cannot be used for modal parameters identification, because it will eventually make the data analysis process suspicious.

In case of seonsor $\# 3,4,5,6,7,8,10$ and 11 , the histograms are very regular and follow the normal distribution and the data from these sensors can be used with full confidence to identify the modal parameters because the results acquired from such kind of data will be accurate and reliable.
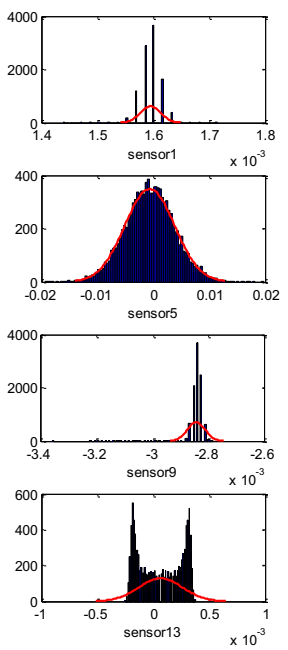
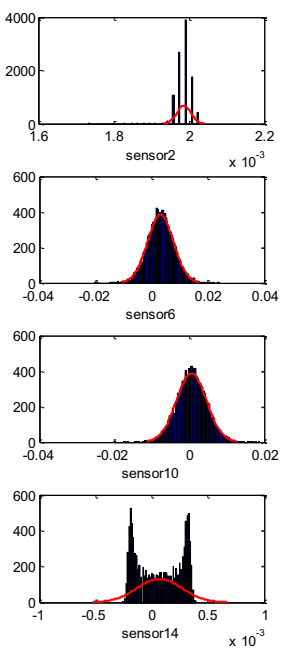
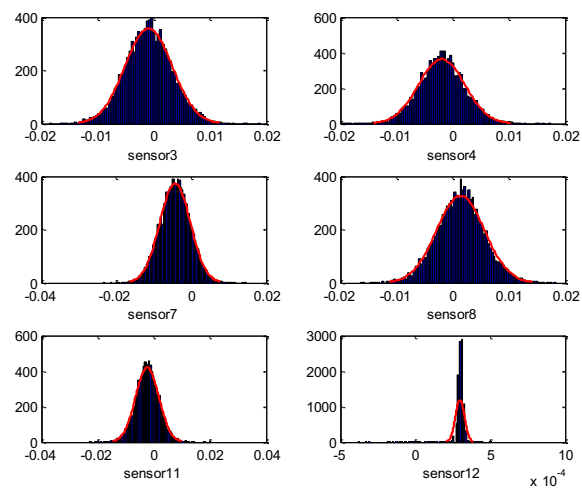

Fig. 5. Histograms 


\subsection{MODAL PARAMETERS}

In the end to perform the modal parameters identification the data acquired from Sutong Bridge for a period of one month form 01-08-2011 to 07-08-2011 was utilized. Sampling frequency for data collection was $20 \mathrm{~Hz}$. The acquired data was first graphically visualized by EDA, then outlier analysis was performed to discard the abnormal data from the sensors, and then finally DATA-SSI technique was engaged to identify the modal parameters such as frequency and damping ratio.

Fig. 6 shows the time evolution of all the frequency identified by the DATA-SSI technique for a time-varying system. The frequencies produced by the ambient vibration of cable stayed bridges as shown in Fig. 6(b) are regular and stable, thus a true representation of the superiority of our proposed method. The identified frequencies shown in Fig. 6(a) are not stable and thus shows that the reliability of data is very important, because if the sensors data is wrong, the identified modal parameters will also be less accurate and will affect the overall identification process.

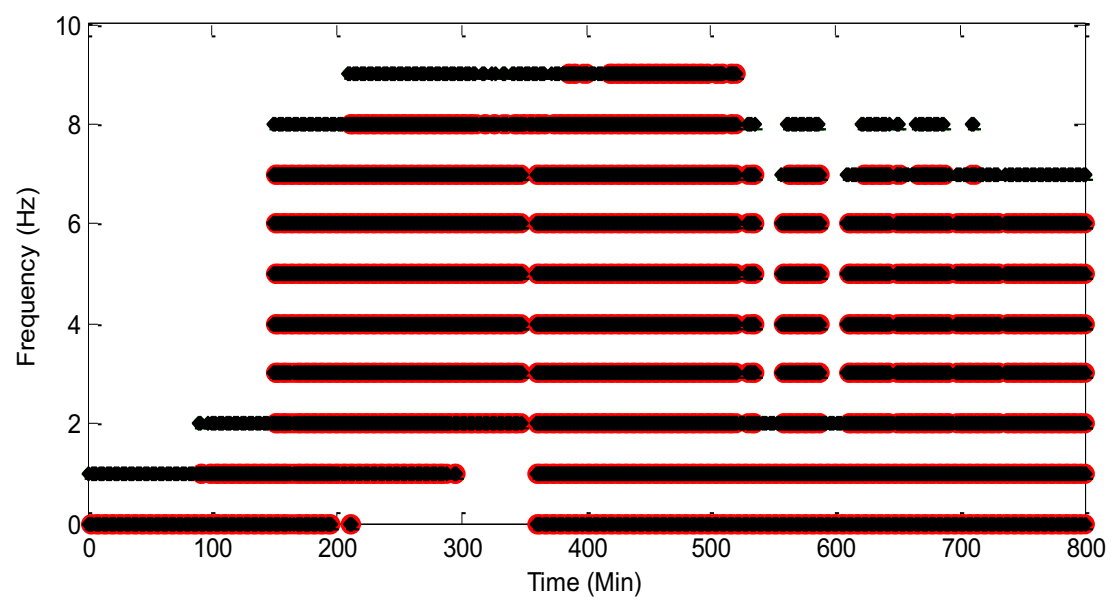

a) Before the proposed method

Fig. 6. Identified frequency 


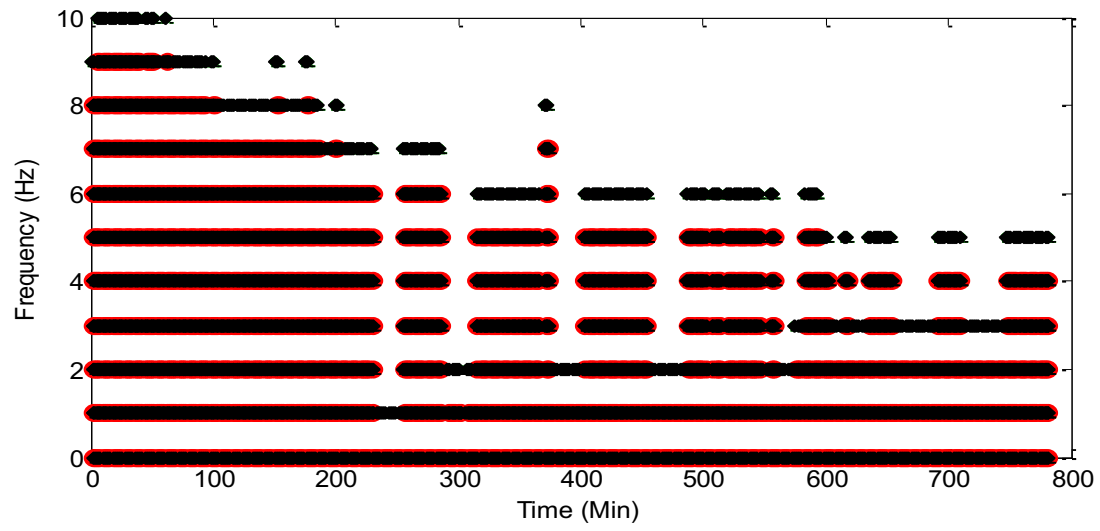

b) After the proposed method

Fig. 6. Identified frequency - continued

Fig. 7 shows the identified damping ratio for time varying system before and after our proposed method. Although the obtained results are not quite clear because of the reason that the identified damping ratios are lower. In case of SSI algorithms the estimation for frequency is good, but for damping ratio it may not be so good, but generally the damping ratio acquired from SSI based algorithms from an ambient vibration data is generally bad due to noise interference. But still the damping ratio acquired in Fig. 7 (b) is better as compare to Fig. 7 (a).

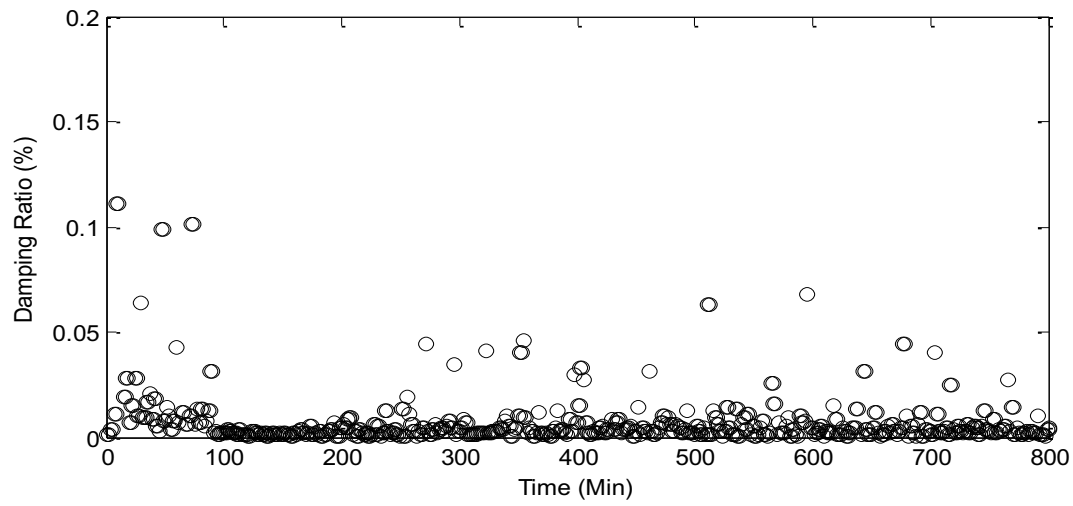

a) Before the proposed method

Fig. 7. Identified damping ratio 


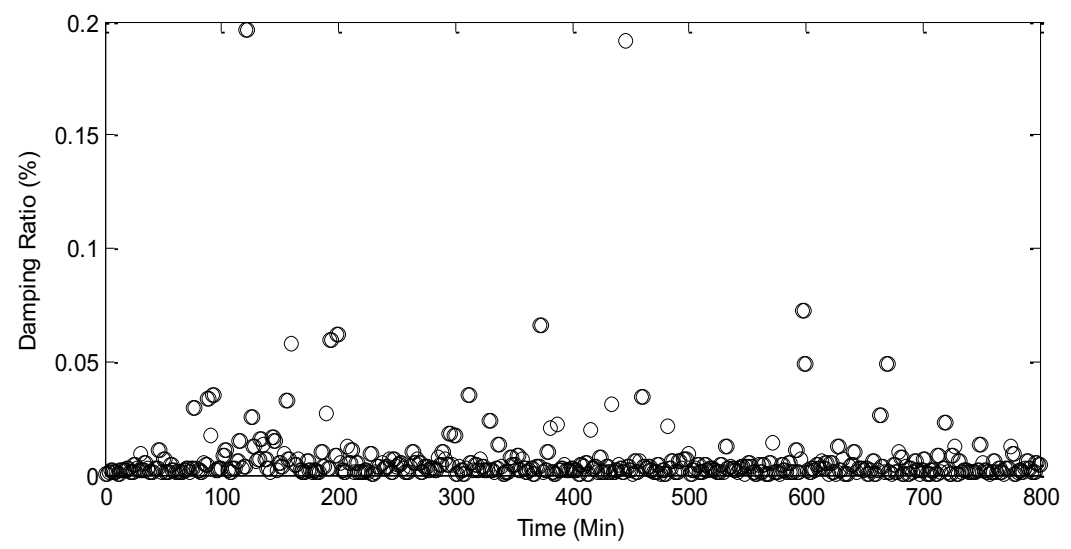

b) After the proposed method

Fig. 7. Identified damping ratio - continued

\subsection{STABLE DiAgRAMS}

In this paper DATA-SSI algorithm is used to process the data. The results obtained from the stabilization diagram are shown in Fig. 8(a) and Fig. 8(b). The stabilization graph obtained after our proposed method shown very convergent properties, and the identified frequencies are more precise, clear and stable as can be seen from Fig. 8(b).

This result can be expected because DATA-SSI algorithm just find a best fit of non-linear signal to a linear system. By achieving thus much accuracy and better results one can conclude that SSI based algorithms can identify an equivalent linear system for non-linear signal effectively and thus the non-linearity of signal does not affect the stabilization diagram.

The factors which affect the stabilization diagram is the faulty and anomalous data acquired from defected sensors, as can be seen in Fig. 8(b). From the stabilization diagram it can be deduced that the proposed method is very effective. 


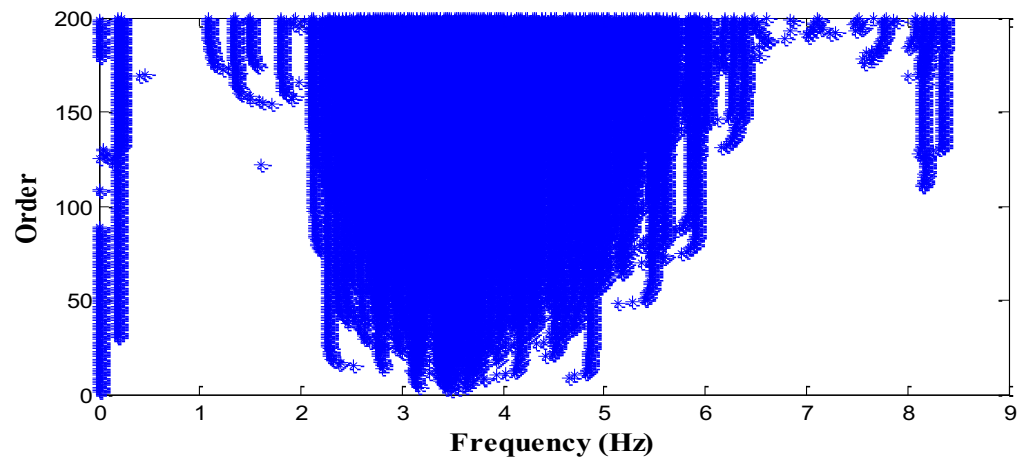

a) Before the proposed method

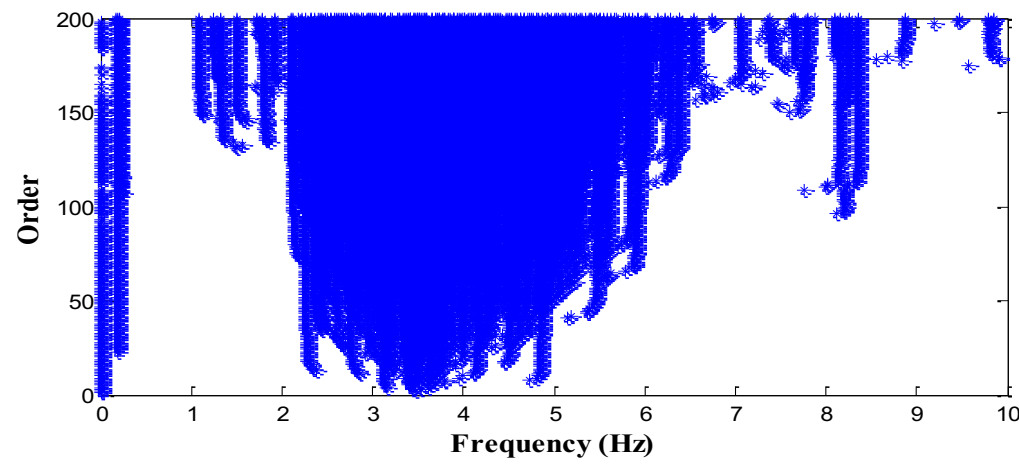

b) After the proposed method

Fig. 8. Stabilization diagram

\section{Conclusions}

The main goal of this paper was to depict the reliability of data acquired from structural monitoring of civil structures especially from long span cable stayed bridges. Since the data acquired from these large span bridges are in huge amount, therefore it is not easy for an engineer to identify the undelaying secrets in the data, thus he needs a tool to quickly access the data. For this purpose a visualization based tool called EDA was introduced. Then outlier analysis was performed on the acquired data to make the data more reliable and to make it flawless. Then DATA-SSI 
technique was introduced, because it is more robust and stable. Based on DATA-SSI modal parameters such as frequency and damping ratio were identified and the results show that, the proposed method is very meritorious. Finally stabilization diagram was plotted to check the preeminence of the proposed method. The results acquired from the above techniques are not only authentic, credible but also very effective and promises better results for real life monitoring.

\section{REFERENCES}

1. I.U. Khan, D.S. Shan, and A.Q. Bhatti, "Temperature Effect Analysis of Viscoelastic Damper and Magnetorheological Damper for Vibration Control of Stayed-Cable", IABMAS2014, Shanghai, China, 2014.

2. I.U. Khan, D.S. Shan, and K. Malik, "Covariance Driven Subspace Identification Technique for Continuous Modal Parameters Identification of Sutong Bridge", IABSE Madrid Symposium: Engineering for Progress, Nature and People, pp 2666-2673(8), 2014.

3. E.J. Cross, K.Y. Koo, J. Brownjohn, and K.Worden, "Long-term monitoring and data analysis of the Tamar Bridge", Mechanical Systems and Signal Processing, 35: pp 16-34, 2013.

4. N. Wu, C. Liu, Y. Guo, and J. Zhang, "On-Board Computing for Structural Health Monitoring with Smart Wireless Sensors by Modal Identification Using Hilbert-Huang Transform”, Mathematical Problems in Engineering, vol. 2012, Article ID 509129, 9 pages, 2013.

5. J.W. Tukey, "Exploratory Data Analysis". Addison-Wesley Publishing Company, ISBN 0-201-07616-0, 1977.

6. J. M. Chambers, "Programming With Data". Springer-Verlag, New York, 1998.

7. W. S. Cleveland, "The Elements of Graphing Data”. Wadsworth Monterey, CA, 1985.

8. W. S. Cleveland, and R. McGill, "Graphical Perception: Theory, Experimentation, and Application to the Development of Graphical Methods", Journal of the American Statistical Association, 79, pp 531-554, 1984.

9. E. R. Tufte, “The Visual Display of Quantitative Information”. Graphics Press Cheshire, CT, 1983.

10. E. R. Tufte, "Envisioning Information". Graphics Press Cheshire, CT, 1990

11. A. Buja, D. Cook, and D. Swayne, "Interactive High-Dimensional Data Visualization, Journal of Computational and Graphical Statistics", 5, pp 78-99, 1996.

12. H. Wainer, "Visual Revelations". Springer-Verlag, New York, 1997.

13. D. R. Brillingera, H. K. Preislerb, A. A. Agerc, and J. G. Kiec, "An exploratory data analysis (EDA) of the paths of moving animals", Journal of Statistical Planning and Inference, 122, pp 43 - 63, 2004.

14. C. Rainieri and G. Fabbrocino, "Operational modal analysis of civil engineering structures". ISBN 978-1-4939-0766-3, Springer, New York, Heidelberg, Dordrecht, London, 2014.

15. Golub, H. Gene, V. Loan, F. Charles, "Matrix computations". Johns Hopkins, University Press, 1996.

16. Pridham, A. Brad and C. J. Wilson, "Identification of base-excited structures using output-only parameter estimation”, Earthquake Eng. Struct. Dyn. 33: pp 133-155, 2004.

17. G. A Smith, A. J. Robinson, "A comparison between the EM and subspace identification algorithms for timeinvariant linear dynamical systems". Cambridge University, 2000.

18. D. J. Yu and W. X, "EMD-based stochastic subspace identification of structures from operational vibration measurements", Engineering Structures Volume 27, Issue 12, pp 1741-1751, 2005.

19. P. V. Overschee and B.D. Moor, "Subspace identification for linear systems: Theory - Implementation Applications", Katholieke Universiteit Leuven, Belgium, Kluwer Academic Publishers, Boston /London/Dordrecht, 1996.

20. J. H. Weng, "Application of Subspace Identification in System Identification and Structural Damage Detection”. Ph.D. Dissertation, National Taiwan University, Taiwan, June 2010.

21. J.H. Weng, C.H. Loh, J.P. Lynch, P.Y. Linn, Y. Wang, "Output-Only Modal Identification of a Cable-Stayed Bridge Using Wireless Monitoring Systems”, Journal of Engineering Structures, 30(2): pp 1802-1830, 2008. 
22. J. B. Bodeux and J.C. Golinval, "Modal identification and damage detection using the data-driven stochastic subspace and ARMAv methods", Mechanical Systems and Signal Processing, 17(1), pp 83-89, 2003.

23. W. X. Ren and Z. H. Zong, "Output-only modal parameter identification of civil engineering structures", Structural Engineering and Mechanics, Vol. 17, No. 3-4, 2004.

24. B. Peeters, and De Roeck, Guido, "Reference-based stochastic subspace identification for output-only modal analysis". Mechanical Systems and Signal Processing 13(6) 855-878, 1999.

25. D. Huston, "Structural Sensing, Health Monitoring, Performance Evaluation". ISBN: 978-1-4200-1235-4, Taylor and Francis Group, LLC, 2011.

26. C. C. Aggarwal, "Outlier analysis". ISBN 978-1-4614-6395-5, Springer New York Heidelberg Dordrecht London, 2013.

27. D. F. Andrews, "Plots of high-dimensional data". Biometrics, 28: pp 125-136, 1972.

28. C. R. Farrar and K. Worden, "Structural health monitoring: A machine learning perspective". John Wiley \& Sons, Ltd, ISBN 978-1-119-99433-6, 2012.

\section{LIST OF FIGURES AND TABLES:}

Fig. 1. Flow Chart for identification process

Rys. 1. Schemat blokowy procesu identyfikacji

Fig. 2. Outlier analysis for sensor \# 3

Rys. 2. Analiza odchyleń - czujnik \# 3

Fig. 3. Control charts

Rys. 3. Wykresy kontrolne

Fig. 4. Andrew curves

Rys. 4. Krzywe Andrewsa

Fig. 5. Histograms

Rys. 5. Histogramy

Fig. 6. Identified frequency

Rys. 6. Stwierdzona częstotliwość

Fig. 7. Identified damping ratio

Rys. 7. Stwierdzony wskaźnik thumienia

Fig. 8. Stabilization diagram

Rys. 8. Diagram stabilizacji 


\section{WYZNACZANIE PARAMETRÓW MODALNYCH MOSTÓW WANTOWYCH NA PODSTAWIE EKSPLORACYJNEJ ANALIZY DANYCH}

Stowa kluczowe: EDA, DATA-SSI, analiza odchyleń, diagram stabilizacji

\section{STRESZCZENIE:}

Jako, że infrastruktura lądowa, a w szczególności mosty o długich przęsłach, ulega z czasem starzeniu, wzrasta również istotność jej zrównoważonej ekonomicznie konserwacji. Ze względu na fakt, że tradycyjne techniki oględzin są zarówno czasochłonne, jak i kosztowne, konieczne jest opracowanie bardziej wiarygodnego i skutecznego systemu monitorowania mostów o długich przęsłach w celu ciągłego monitorowania zachowania się konstrukcji na podstawie szybkiej i dokładnej analizy danych. Ponieważ system monitorowania wykazuje anomalie w wyniku wadliwego funkcjonowania czujników lub awarii systemu, konieczne jest opracowanie efektywnej i skutecznej techniki, która umożliwi szybkie wykrywanie takich anomalii oraz prezentowanie ich w sposób bardziej profesjonalny. Dlatego w niniejszym opracowaniu przedstawiono metodę Eksploracyjnej Analizy Danych (EAD).

Od kilkudziesięciu lat, wyznaczanie parametrów modalnych odgrywa coraz większą rolę, ponieważ dostarcza innowacyjnych narzędzi, umożliwiających zrozumienie i kontrolowanie optymalizacji projektu oraz oceny wytrzymałości konstrukcyjnej obiektu. Istnieje szereg technik SSI, takich, jak Covariance Driven SSI, Data Driven (DATA-SSI), jak również kombinacje innych metod, takich, jak techniki SSI Expectation Maximization (EM-SSI) czy Empirical Mode Decomposition (EMD). Niniejsze opracowanie opisuje zastosowanie techniki DATA-SSI z pewnymi ulepszeniami w odniesieniu do faktycznie istniejącego mostu o długich przęsłach.

W przypadku danych gromadzonych na dużą skalę, zrozumienie zestawów danych zawierających cokolwiek więcej, niż tylko szereg punktów danych bez zastosowania efektywnej techniki jest praktycznie niemożliwe. Ponieważ dane gromadzone w trakcie monitorowania stanu mostów mają z reguły ogromną objętość, a niewiele wiadomo na temat funkcji gęstości prawdopodobieństwa (PDF), zawsze zaleca się, aby inżynier przeanalizował dane w celu określenia i wskazania najważniejszych cech danych, zanim zastosuje techniki ilościowe; podstawową przeszkodą dla inżyniera jest w tym wypadku czas. EDA to najpotężniejsze narzędzie, wspomagające eksplorowanie „wewnętrznych sekretów” danych w sposób szczegółowy przy znacznym ograniczeniu czasu trwania obliczeń. Eksploracyjny charakter EDA może okazać się wystarczający dla wielu zastosowań SHM. Jakkolwiek istnieje wiele technik graficznej reprezentacji danych, w niniejszym opracowaniu omówimy zaledwie kilka z nich, aby zilustrować dokładność i skuteczność EDA - takie, jak wykresy kontrolne, krzywe Andrewsa oraz histogramy.

W przypadku faktycznie istniejących konstrukcji lądowych na wielką skalę, w danych zawsze pojawiają się szumy i zniekształcenia; zasadniczo, nie istnieją z góry zdefiniowane informacje na temat liczby modułów podlegających przetworzeniu. Podstawową przyczyną tego stanu rzeczy są niepewności związane z określeniem rzędu układu. Dlatego używa się diagramu stabilizacji w celu rozróżnienia pomiędzy szumami lub fałszywymi biegunami a prawdziwymi biegunami układu. Diagram stabilizacji jest de facto rysunkową ilustracją występowania biegunów przy tej samej częstotliwości w wyniku zwiększania rzędu modelu modalnego w celu przedstawienia stanu fizycznego rzędu układu. Na podstawie procedury DATA-SSI, diagram stabilizacji wykreślono dla danych otrzymanych dla mostu Sutong. Most Sutong jest to most nad rzeką Jangcy i jeden z najdłuższych mostów wantowych, łączący Changshu i Nantong. 
Jest to most o siedmiu przęsłach, dwupylonowy, wantowy, w formie stalowej konstrukcji skrzynkowej o rozpiętości najdłuższego przęsła wynoszącej 1088m, przy czym łączna długość mostu wynosi:

$$
100+100+300+1088+300+100+100=2088 \mathrm{~m} \text {. }
$$

Aby wyznaczyć parametry modalne mostu Sutong, pobrano dane z 14 czujników - akcelerometrów, zainstalowanych na moście. Ogromna ilość danych, pobranych z systemu SHM na moście Sutong, została w pierwszej kolejności poddana wizualizacji przy pomocy EDA, aby określić najważniejsze tendencje oraz trendy w danych, ponieważ reprezentacja graficzna danych jest szybka i dokładna oraz umożliwia ogromną oszczędność czasu w porównaniu z technikami obliczeniowymi. Następnie przeprowadzono analizę odchyleń w celu odrzucenia ze zbioru danych budzących wątpliwości. Następnie wprowadzono technikę DATA-SSI, zapewniającą większą niezawodność i stabilność wyników.

Na podstawie DATA-SSI określono parametry modalne, takie, jak częstotliwość czy wartość tłumienia, a wyniki wskazują, że proponowana metoda znakomicie broni się merytorycznie. Następnie sporządzono diagram stabilizacji, aby zweryfikować stwierdzony wstępnie prymat metody.

Wyniki, pozyskane za pomocą wyżej wymienionych technik, są nie tylko autentyczne, ale też niezwykle efektywne, co sugeruje możliwość znaczącej poprawy rezultatów monitoringu, prowadzonego w terenie. 